\title{
Unusual Neurologic Manifestations Associated with Epstein-Barr Virus Infection
}

\author{
Tomohiko Mizutani, Atsuko Murashima*, Ryoichi Shiozawa* and Satoshi Kamei
}

\begin{abstract}
We describe two patients who displayed unusual neurologic manifestations associated with reactivation of latent Epstein-Barr virus (EBV) infection. The patients included a 34-year-old woman who suffered from meningoencephalitis presenting with symptoms identical to those of transient global amnesia, and a 57-year-old man with jumbling phenomenon and gait ataxia. The protean neurologic manifestations of EBV infection underscore the need to suspect this infection in any acute neurologic disorders of possible infectious origin irrespective of the age of the patient.
\end{abstract}

(Internal Medicine 32: 36-38, 1993)

Key words: Epstein-Barr virus, neurologic manifestation, transient global amnesia, jumbling phenomenon, gait ataxia

\section{Introduction}

Epstein-Barr virus (EBV) infection may cause various neurologic disorders involving any site within the nervous system $(1,2)$. The introduction of EBV-specific serologic testing has facilitated the identification of the association of some of the acute neurologic disorders with EBV infection, even when they represented uncommon or unusual manifestations of this infection $(3-8)$. The recently reported complications include status epilepticus $(4,8)$, psychosis (5), chorea (5), recurrent myoclonus (6) and chiasmal neuritis (7), and the majority of these $(3-5,7,8)$ and previous findings were related to primary EBV infection. Recently, it has become apparent that reactivation of latent EBV infection, persistent or recurrent EBV infection may occur in some patients $(5,6,9$, 10 ), and EBV infection involves not only young people, but also affects older people (11).

We describe here two patients aged 34 and 57 years, respectively, who presented with unusual neurologic manifestations associated with reactivated EBV infections.

\section{Case Reports}

Case 1

A 34-year-old woman was admitted because of fever, headache and transient loss of memory. Seven days prior to admission, the patient came to the otorhinolaryngology clinic of our hospital due to aphthous stomatitis and pharyngitis. Two days later, she developed fever of $39.6^{\circ} \mathrm{C}$ and severe headache. The next day, she lost her memory over a duration of about 6 hours: she could recall when she awoke at about 9:30 am, but she did not remember thereafter until the late afternoon on the same day. During that period, the patient came to the clinic at her appointment time by taking commuter trains and subway, then went to a bank to deposit money, and after returning home received a call from her office. When she received a further call later on the same afternoon, she was told that she didn't know the date of the day of the previous call, and she realized her memory loss.

Neurologic examinations on the next day revealed that she was mentally alert and well oriented, but exhibited a slow response and some mistake in calculation. Other neurologic abnormalities were not detected. Laboratory data on the same day showed a white blood cell count of 12,400/cubic mm without atypical lymphocytes, and an erythrocyte sedimentation rate of $62 \mathrm{~mm} /$ hour. Her cerebrospinal fluid (CSF) revealed a normal opening pressure, a cell count of 141/cubic mm with 53 polymorphonuclear cells, 59 lymphocytes and 29 other cells, a total protein of $42 \mathrm{mg} / \mathrm{dl}$ and a sugar level of $61 \mathrm{mg} / \mathrm{dl}$. An electroencephalogram (EEG)

From the Department of Neurology, Nihon University School of Medicine, Tokyo and *the Division of Neurology, Toranomon Hospital and Okinaka Memorial Institute for Medical Research, Tokyo

Received for publication June 11, 1992; Accepted for publication November 9, 1992

Reprint requests should be addressed to Dr. Tomohiko Mizutani, the Department of Neurology, Nihon University School of Medicine, 30-1 Kami-machi, Ohyaguchi, Itabashi-ku, Tokyo 173, Japan 


\section{EB Virus and Neurologic Manifestations}

demonstrated a basic activity of $40 \mu \mathrm{V}, 8 \mathrm{~Hz}$ activity mixed with a small amount of 5 to $6 \mathrm{~Hz}$ activity, occasional bilateral sharp waves in the parieto-posterior temporo-occipital areas and a few synchronous bursts of 4 to $5 \mathrm{~Hz}$ without asymmetric abnormalities.

The patient was admitted 3 days later because of CSF pleocytosis. On admission, she was neurologically normal. Cranial computerized tomographic scans (CTs) with and without contrast medium demonstrated a normal brain. Among the measured antibody titers for 24 viruses including herpes viruses and for mycoplasma pneumoniae, only those for EBV were significantly increased (Table 1). The Paul-Bunnel reactions yielded negative results. The patient was discharged without any neurologic sequelae 4 weeks later.

\section{Case 2}

A 57-year-old man with a history of moderate alcohol intake developed fever of $39.0^{\circ} \mathrm{C}$ and unsteadiness in his gait to both sides. He also felt that viewed objects appeared to oscillate to-and-fro or side to side, particularly when he moved his head fast, consistent with jumbling phenomenon (12). He was prescribed drugs for his "common cold", but denied any intake of other drugs. The fever resolved within one week. Neurologic examinations at two weeks after the onset of fever revealed mildly wide-based gait, an inability to perform tandem gait, and mild bilateral terminal tremor in finger-tonose tests. Nystagmus was not observed. Otherwise, the patient was unremarkable, including the findings for the cranial nerves, deep tendon reflexes, muscle strength and tone, and sensory system.

Table 1. Serologic Studies for Epstein-Barr Virus (EBV) in the Blood and Cerebrospinal Fluid (CSF)

\begin{tabular}{|c|c|c|c|c|c|c|}
\hline \multirow[b]{3}{*}{ Case } & \multirow{3}{*}{$\begin{array}{c}\text { Time after onset of } \\
\text { neurologic symptoms }\end{array}$} & \multicolumn{5}{|c|}{ Antibodies to EBV-related antigen } \\
\hline & & \multicolumn{2}{|c|}{ Serum VCA } & \multirow{2}{*}{$\frac{\mathrm{CSF}}{\mathrm{VCA}-\mathrm{IgG}}$} & \multicolumn{2}{|c|}{ Serum } \\
\hline & & IgG & $\operatorname{IgM}$ & & EA & EBNA \\
\hline \multirow[t]{4}{*}{1} & 2 days & 160 & NR & 8 & ND & 10 \\
\hline & 6 weeks & 1,280 & NR & 2 & 80 & 80 \\
\hline & 10 weeks & 1,280 & ND & 1 & 10 & 40 \\
\hline & 4 months & 640 & ND & ND & 10 & 80 \\
\hline \multirow[t]{3}{*}{2} & 13 days & 160 & $<10$ & $<1$ & ND & 10 \\
\hline & 4 weeks & 160 & $<10$ & $<1$ & ND & ND \\
\hline & 6 months & 40 & ND & ND & ND & 40 \\
\hline
\end{tabular}

VCA indicates viral capsid antigen. EA: EBV-associated early antigen, where the EA values represent the sum of both the diffuse and restrictive components of EA, EBNA: EBV-associated nuclear antigen, NR: values not reliable because of non-specific immunofluorescence caused by rheumatoid factor which was present in the serum of case 1, ND: not done. Tests were performed at the Special Reference Laboratory, Tokyo, Japan, using indirect immunofluorescent tests for VCA-IgG, VCA-IgM and EA as well as the immunofluorescence complementfixation test for EBNA.
Initial routine laboratory data were normal, including the blood cell counts and differentials among white blood cells, except for an erythrocyte sedimentation rate of $26 \mathrm{~mm}$ /hour and C-reactive protein of $1+$. Lumbar puncture revealed CSF with a normal opening pressure, a cell count of 30 /cubic mm consisting of 2 polymorphonuclear cells and 28 lymphocytes, and normal values for sugar and total protein. Antibody titers for 12 viruses and mycoplasma pneumoniae demonstrated elevated serum titers of EBV only (Table 1). The Paul-Bunnel reactions yielded negative results. CTs revealed a normal brain. Neuro-otologic examinations at about 3 months after the onset of illness showed that the responses to the cold caloric test were markedly reduced in the left ear and abolished in the right ear. Positional nystagmus was not observed, and optokinetic nystagmus pattern tests yielded normal results. In addition, an audiogram showed a sensorineural hearing loss of $40 \mathrm{~dB}$ in the left ear and $70 \mathrm{~dB}$ in the right ear at $8,000 \mathrm{~Hz}$ only.

The patient was initially given prednisolone at $50 \mathrm{mg} /$ day for one week, which was then gradually tapered off. The gait ataxia in this patient underwent moderate improvement over 9 months, whereas his jumbling phenomenon improved only slightly.

\section{Discussion}

Our patients displayed neurologic manifestations which were unusual among those associated with EBV infection: symptoms identical to those of transient global amnesia (TGA) occurred as the only encephalitic symptoms in case 1; and jumbling phenomenon (12) also termed oscillopsia (13) was noted in case 2 who additionally developed gait ataxia.

TGA, most commonly caused by transient cerebral ischemia, is also known to be caused by or associated with various other conditions such as brain tumor, migraine and epilepsy (14). To our knowledge, TGA due to encephalitis has been reported only once, by Pommer et al (15). Their patient suffered EBV encephalitis which gave rise to uncinate fits and generalized convulsions as well. Jumbling phenomenon, as observed in case 2, is commonly caused by lesions of the vestibular system, particularly by ototoxic drugs such as streptomycin (12), and also by brainstem lesions and seizures due to cerebral lesions as well as drug toxicity such as that of diphenylhydantoin (13). Although gait ataxia of case 2 was likely due to "cerebellitis", we consider that his jumbling phenomenon was most probably caused by vestibular dysfunction due to EBV infection, since he displayed marked bilateral abnormalities in the cold caloric test (12), and he did not display brainstem signs or have a history of intake of ototoxic drugs. Although sensorineural hearing loss has been described in EBV infection (16), jumbling phenomenon has not been reported previously in EBV infection. It was unclear whether 
bilateral sensorineural hearing loss of case 2 was related EBV infection because of the undetermined onset of his hearing loss.

The diagnosis of EBV infection in the present cases was supported by 4-fold or greater changes in the antiEBV VCA IgG titers $(3,17)$, and also by a subsequent rise of anti-EBNA antibody titers $(3,17,18)$. These serological changes and initial low titers of anti-EBNA antibody indicate that our cases suffered from reactivation of latent EBV infection, since anti-EBNA antibody titers usually rise weeks or months after primary EBV infection (17) and persist at low detectable levels for life $(17,18)$, such that low titers of this antibody indicate the occurrence of previous EBV infection. It should be mentioned, however, that reinfection by EBV cannot be ruled out in these two cases, and that the possibility of primary EBV infection cannot be excluded in case 2, since a few patients may show a rise in antiEBNA antibody titers within $1-3$ weeks after the onset of EBV infection (18). Elevation of the anti-early antigen (EA) antibody titers also suggested the occurrence of EBV infection in case 1, although the titers did not indicate whether or not the EBV infection has occurred acutely, since their values represented the sum of both the diffuse and restrictive components of anti-EA antibody, and the diffuse component transiently appears during the acute phase of EBV infection, whereas the restrictive component develops later (17). The rise and subsequent decline of anti-VCA-IgG titers observed in the CSF of case 1 might indicate EBV infection as well. However, this could have been due to passive transfer of the antibody from the patient's serum to CSF because the serum-to-CSF ratio of this antibody was found to be 20 or more (19).

In summary, our report further indicates the occurrence of various neurologic manifestations and reactivation of latent $\mathrm{EBV}$ infection, as well as the need to perform serial EBV-specific serologic studies in all patients with acute neurologic disorders of undetermined and possible infectious etiology irrespective of the age of the patient.

Acknowledgement: We thank Professor Toshiaki Takasu, Department of Neurology, Nihon University School of Medicine, Tokyo, for his encouragement.

\section{References}

1) Silverstein A. EB virus infections of the nervous system. in:
Handbook of Clinical Neurology, Vinken PJ, Bruyn GW, Eds. North-Holland Publishing Company, Amsterdam, 1978, vol 34, p. 185.

2) Gotlieb-Stematsky T, Arlazoroff A. Epstein-Barr virus. in: Handbook of Clinical Neurology, Vinken PJ, Bruyn GW, Klawans HL, McKendall, Eds. Elsevier Science Publishers, New York, 1989, vol 12 (56), p. 249.

3) Grose C, Henle W, Henle G, Feorino PM. Primary EpsteinBarr-virus infections in acute neurologic diseases. N Engl J Med 292: 392, 1975.

4) Russell J, Fisher M, Zivin JA, Sullivan J, Drachman DA. Status epilepticus and Epstein-Barr virus encephalopathy: diagnosis by modern serologic techniques. Arch Neurol 42: 789, 1985.

5) Leavell R, Ray CG, Ferry PC, Minnich LL. Unusual acute neurologic presentations with Epstein-Barr virus infection. Arch Neurol 43: 186, 1986.

6) Mizutani T, Ida M, Egarashi O, Daida H, Shiozawa R. Recurrent myoclonus associated with Epstein-Barr virus infection in an elderly patient. Rinsho Shinkeigaku 26: 1042, 1986 (in Japanese with English abstr).

7) Purvin V, Herr J, De Myer W. Chiasmal neuritis as a complication of Epstein-Barr virus infection. Arch Neurol 45: 458, 1988.

8) Kubota F, Shiihara Y, Takahashi S. A case of Epstein-Barr virus encephalitis presenting as status epilepticus. Rinsho Shinkeigaku 28: 751, 1988 (in Japanese with English abstr).

9) Tobi M, Morag A, Ravid Z, et al. Prolonged atypical illness associated with serological evidence of persistent Epstein-Barr virus infection. Lancet I: 61, 1982.

10) Straus SE. Relapsing, recurrent, and chronic infectious mononucleosis. in: Epstein-Barr Virus and Associated Diseases, Levine PH, Ablashi DV, Pearson GR, Kottaridis SD, Eds. Martinus Nijhoff, Boston, 1985, p. 18.

11) Edelstein H, Knight RT. Epstein-Barr virus causing encephalitis in an elderly woman. S Med J 82: 1192, 1989.

12) Hiwatashi $S$, Nakanishi $K$, Tamasa A, Miyoshi $T$. Twenty two cases of the jumbling phenomenon. Otorhinolaryngol Clin (Tokyo) 75: 230, 1982 (in Japanese with English abstr).

13) Bender M.B. Oscillopsia. Arch Neurol 13: 204, 1965.

14) Caplan LB. Transient global amnesia. in: Handbook of Clinical Neurology, Vinken PJ, Bruyn GW, Klawans HL, Frederiks JAM, Eds. Elsevier Science Publishers, New York, 1985, vol 1 (45), p. 205.

15) Pommer B, Pilz P, Harrer G. Transient global amnesia as a manifestation of Epstein-Barr virus encephalitis. J Neurol 229: 125, 1983.

16) Beg JA. Bilateral sensorineural hearing loss as a complication of infectious mononucleosis. Arch Otolaryngol 107: 620, 1981.

17) Henle G, Henle W. The virus as the etiologic agent of infectious mononucleosis. in: Epstein-Barr Virus, Epstein MA, Achong BG, Eds. Springer-Verlag, Berlin, 1979, p. 297.

18) Henle G, Henle W, Horwitz CA. Antibodies to Epstein-Barr virus-associated nuclear antigen in infectious mononucleosis. $\mathrm{J}$ Infect Dis 130: 231, 1974.

19) Nahmias AJ, Whitley RJ, Visintine AN, Takei Y, Alvord Jr CA, the Collaborative Antiviral Group. Herpes simplex virus encephalitis: laboratory evaluations and their diagnostic significance. J Infect Dis 145: 829, 1982. 